\title{
Preliminary Note on the Comparative Anatomy of Cucurbitaceæ, wild and cultivated in Japan.
}

by

\section{Atsushi Yasuda, Rigakushi.}

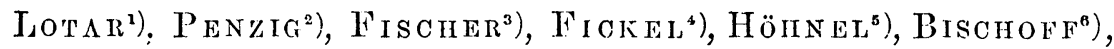
$\mathrm{HARZ}^{7}$ ), Frímonts), and others have early investigated the anatomical characters of Cucurbitacece, bringing to light the special structures of various organs. I undertook, for my part, to study comparatively some differences existing in the inner structures of Cucurbitacere found wild and cultivated in our country. In Japan the number of genera contained in this family is nowadays known to be fifteen: Actinostemma, Benincasa, Bryonopsis ${ }^{9}$, Citrullus, Cucumis, Cucurbita, Gymnostemma, Lagenaria, Lauffa, Melothria,

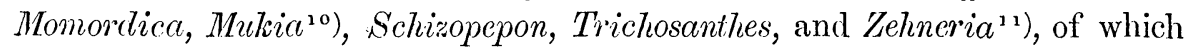
I examined twelve genera, Bryonopsis, Mukia, and Zehneria having been inaccessible to me.

I investigated the anatomical structures of the stems, hypocotyls, blades,

1) Henri-Aimé Lotar. Essai sur l'Anatomie comparée des organes végétatifs et des téguments séminaux des Cucurbitacées. Lille 1881.

2) O. Penzig. Zur Verbreitung der Cystolithen im Pflanzenreich. Bot. Centralbl. 1881. Bd. VIII., No. 13.

3) A. Fischer. Untersuchungen über das Siebröhrensystem der Cucurbitaceen. Bot. Centraibl. 1885. Bd. XXI, No. 4.

4) J. F. FickEx. Ueber die Anatomie und Entwicklungsgeschichte der Samenschalen einiger Cucurbitaceen. Bot. Ztg. 1876. Bd. XXXIV, Nr. 47-50.

5) F. v. Hörnel. Morphologische Untersuchungen über die Samenschale der Cucurbitaceen. Wien 1876.

$\left.{ }^{6}\right)$ G. W. BIschoff. Handbuch der botanischen Terminologie und Systemkunde. Nürberg 1833. Bd. I.

7) C. I). HARz. Landwirthschaftliche Samenkunde. 1885. Bd. II.

${ }^{8}$ ) A. Frínont. Sur les tubes criblés extra-libériens dans la racine des Oenothéracées. Journ. de Botanique. 1891. T. 5.

9) H. KURoIwA. A List of Phanerogams collected in the Southern Part of Okinawa, an Island of the Loochoo Chain. Botanical Magazine. Tokyo. 1900. Vol. XIV, No. 163. p. 123.

10) H. KUROIWA. loc. cit. p. 123.

11) H. KuRoIwa. loc. cit. p. 123. 
petioles, cotyledons, tendrils, roots, fruits, and seeds of the above plants, and when necessary old as well as young specimens were examined and compared. Here, however, instead of entering into detailed descriptions, I will give the chief results of my investigation piece by piece as a preliminary note.

(1) The old stems of Iuffa and Momordica are very characteristic. They have a sharp keel along the angled portions. 'The microscopical examination shows that the ridges of $L u f f a$ consist only of the outgrowth of the collenchyma, while those of Momordica are formed by newly developed secondary fibro-vascular bundles.

(2) There are four types ${ }^{1}$ ) of the distribution of the sieve-tules in the stems: $a$ ) the vascular-bundle sieve-tubes, $b$ ) the ectocyclic sieve-tubes, $c$ ) the entocyclic sieve-tubes, and $d$ ) the commissural sieve-tubes. Luffa, Momordica, Gymnostemma, and Actinostemma have those of the first and third types; Lagenaria, Benincasa, Cncumis, Trichosanthes, Citrullus, Schizopepon, and Melothria those of the first, third, and fourth types; and Cucurlita all kinds of them.

(3) Rhizomes occur in Melothria and Crymnostemma. They are long and thick, having scales at several nodes and are full of starch-grains, of which those of Gymnostemma are the largest $(0.06 \mathrm{~mm}$. in diameter) among the starch-grains contained in any organs of Cucurbitacea.

(4) The number of the fibro-vascular bundles in the hypocotyls is generally six, ${ }^{2}$ ) except in Citrullus and Cucurbita, the former of which has twelve, and the latter ten.

(5) The epidermal cells on the upper surface of the blades of Trichosanthes cucumeroides are elongated into conical papille.

(6) The epidermis of the blades may be many-layered as in Cucurbita, a character which is limited to this genus. Momordica contains globular cystoliths ${ }^{3}$ ) in the greatly enlarged epidermal cells on the lower surface of the blade. They are united into groups.

(7) Stomata on the upper surface of the hlades are rarely found in Momordica charantia and Trichosanthes japmica, while they are entirely wanting in Schizopepon and Gymnostemma.

(8) The mesophyll of Actinostemma is very rich in intercellular spaces, so that it reminds us of the leaf-tissue of water plants.

1) Compare the work of A. Fiscrinn, Inc. rit. p. 104-10s.

2) Henri-Aimé Lotar. loe. eit. p. 14.

s) O. Penzig. loc. cit. p. 393. 
(9) Pallisade parenchyma mostly occupies forr-tenths of the thickness of the blades, sometimes exceding six-tenths in Cucurbita P'epo, where the pallisade cells may be arranged in double rows.

(10) 'The petioles are solid in general, excepting in Cucurbita and Benineasa, in which they are hollow. The number of fibro-vascular bundles varies fiom 5) (Actinostemma, Melothria, and Gymnostemma) to 13 (Cucurlita).

(11) Stomata on the cotyledons are in many cases present on both the upper and lower surfaces. Momordica charantia, Trichosanthes japonica, and Gymnostemma cissoides form an exception to this rule, the former two having the stomata on the lower surface and very rarely on the upper surface, while the last one has them exclusively on the under side.

(1.2) The number of stomata found on the tendrils is nearly the same in all species. The number of fibro-vascular bundles varies from 4 (Actinostemma, Gymnostemma) to 9 (Citvullus).

(13) Tubers are confined to the genus Triehonsuntlies. The largest starch-grains contained in the roots are those from the tubers of Trichosanthes multiloba $(0.04 \mathrm{~mm}$. in diameter).

(14) In the old roots of Momordica the fibro-vascular bundles have a double arrangement at the angled portions as in the old stems.

(15) The young root; of Actinostemma have remarkably wide intercellular spaces.

(16) The epidermal cells of the fruits may be radially flattened, culical, and radially elongater. Cucumis sativus is characterized by having the epidermal cells four times longer radially than tangentially, and Benincasa hispida by having a tangential septum in many cells.

(17) In the fruit-tissue a sclerenchymatous ring, rither complete or incomplete, is generally formed. In Cucurbita, Sclizopepon, Curumis sativus, and C. Mlelo, however, it is entirely absent.

(18) The anatomical structure of the fibro-vascular bundles of the Lu:ffa-fruit deserves notice by the fact that the well-developed sclerenchyma surrounds the remaining weakly-dereloped portion of the bundle, the whole forming a spongy tissue.

(19) Into the tubercles on the surface of the fruit of Momordica charantia a branch of the fibro-vascular bundles enters. Nothing of this kind can be observed in other genera.

(20) The sieve-tubes have a characteristic distribution in the fruits. Besides those found in the phloem there are isolated sieve-tubes in the 
cortex. These extra-phloem sieve-tubes occur in the hypoderma outside of the stiffening ring. And when no stiffening ring is present they are found in the outer part of the cortex.

(21) We may distinguish three kinds of the epidermal cells of the seeds: a) flattened cells, b) prismatic cells, c) prismatic cells with ridges on their walls. To the first type belong Actinostemma, Gymnostcmma, and Trichosanthes japonica; to the second Benincasa, Luffa, Momordica, and Trichosanthes cucumeroides; to the third Citrullus, Cucumis, Cucuibita, Lagenaria, Melothria, and Schizopepon.

In conclusion I wish to express my hearty thanks to Prof. Dr. J. MATSUMURA, under whose care I conducted my investigations. I am also very thankful to Mr. Y. 'I'Anaka, Dr. K. MiYabe, Mr. 'T. Makino, and Mr. T. YoshinaGa, who kindly gave ne valuable materials.

Sendai, February 25, 1901.

\title{
Observations on the Flora of Japan.
}

\author{
(Continued from p. 84.) \\ By \\ T. Makino, \\ Assistant in the Bolanical Institute, Science \\ College, Imperial University of Toliyo.
}

Gilibertia trifida (Thunb.) Makino nom. nov.

Acer trifidum 'Thunb. Fl. Jap. p. 163 ; Pers. Syn. Pl. II. p. 418 ; Willd. Sp. Il. IV. p. 991 ; Spreng. Syst. Veg. II. p. 224 ; DC. Prodr. I. p. 595.

Dendropanax trifidus Makino in Herb. Se. Coll. Imp. Univ. Tokyo.

Hedera japonica Jungh. 1840 ; Walp. Repert. II. p. 431.

Textoria japonica Miq. Araliacee in Ann. Mus. Bat. Iungd.-Babav. 1. p. 12 ; Il. Prol. Fl. Jap. 1. 90 ; Id. Cat. Mus. Bot. Tugd.-Bat., Fl, Jal. p. 43.

Dendropanax japonicus Seem. Journ. Bot. II. p. 301, et Revis. Heder. p. 27 ; Benth. et Hook. fil. Gen. Pl. I. p. 944 ; Franch. et Sav. Enum. Pl. Jap. I. p. 194; Kanitz Anthoph. Jal. p. 28 ; Clarke in Hook. fil. Fl. Brit. Ind. II. p. 733 ; Engl. in Engl. Bot. Jahrb. VI. p. 61 ; Forbes et Hemsl. in Journ. Linn. Soc. XXIII. p. 342. 